\title{
Dimensions and Indicators for Sustainable Construction Materials: A Review
}

\author{
Humphrey Danso* \\ Department of Construction and Wood Technology, Ghana \\ *Corresponding author: Humphrey Danso, Department of Construction and Wood Technology, P.O. Box 1277, Kumasi, Ghana \\ Submission: 悳 December 21, 2017; Published: 些 February 19, 2018
}

\begin{abstract}
Sustainable construction practices are provided to reduce resource depletion and prevent environmental degradation caused by construction activities and products. The purpose of this paper is to review the general and relevant available indicators for measuring sustainable construction materials. The paper outlines the main idea behind sustainability assessment. It also reviews the critical sustainability indicators which are grouped under the 3Es, thus environmental, social equity and economic dimensions. Furthermore, it highlights the analytical hierarchical process in sustainable construction materials assessment. The paper concludes that it is important to identify the relevant sustainable indicators for construction materials and be able to measure the indicators following the analytical hierarchical process.
\end{abstract}

Keywords: Construction materials; Sustainable construction; Sustainable indicators

\section{Introduction}

Sustainability is a concept which is concern with the environmental, social and economic development in different specializations such as economics, engineering, construction, ecology and health to meet the present and future needs. Sustainable construction is therefore the adoption of materials and products in buildings and construction that will require less use of natural resources and increase the reusability of such materials and products for the same or similar purpose Keung [1]. Building construction and operations have significant direct and indirect impacts on the environment (Wahlström et al. [2]). The current mainstream building materials and methods are producing large amounts of $\mathrm{CO}_{2}$ both during construction and throughout a building's life (Peach [3]). According to Khatib [4] construction managers, researchers and academics have a major role to play in sustaining our environment, through efficient utilisation of natural resourced, re-use and recycling.

The main objectives of sustainable construction activities are to avoid resource depletion of energy, water, and raw materials and prevent environmental degradation caused by facilities and infrastructure throughout their life cycle (Wahlström et al. [2]). The sustainability of construction technology and materials is increasingly on the international agenda, as demonstrated by Environmental assessment tools such as BREEAM (Building Research Establishment Environmental Assessment Method) in the UK, and LEED (Leadership in Energy and Environmental Design), its equivalent in the USA (Fielding et al. [5]).

Example of sustainable materials include wool bricks, solar tiles, sustainable concrete, paper insulation, triple-glazed windows
(Peach [3]). For construction of walls, earth-based technologies offer the best solutions for long-term sustainable construction development. Rammed earth (RE) and stabilised soil block (SSB) techniques appear to be the most appropriate, with the added advantage of providing culturally acceptable solutions in subSaharan Africa (Fielding et al. [5]). The choice of materials will be heavily influenced by what is available locally, following the principle of minimising transport costs as well minimise the use of high energy materials, such as metal and cement (Fielding et al. [5]).

Sustainable construction has three main dimensions: environment, social and economic. Each of these dimensions can be characterised by number of indicators. The indicators available in literature are provided in different forms depending on the focus of each study, without considering construction materials in general. This paper therefore provides a review of the general and relevant available indicators for measuring sustainable construction materials. The review consists mainly of sustainability assessment, sustainability indicators, environmental dimension, social dimension and economic dimension for construction materials and analytical hierarchical process in sustainable construction materials assessment.

\section{Sustainability Assessment}

Sustainability is a highly integrated concept, whereby environmental, social and economic factors are decidedly interrelated (Mailler [6]). Sustainability requires the reconciliation of environmental, social equity and economic demands, also known as the " 3 Es" or the " 3 pillars" of sustainability. The term sustainability 
can simply mean to 'maintain', 'support', or 'endure' something. However, since the 1980s sustainability has been used more in the sense of human sustainability on planet Earth. This has resulted in the most widely quoted definition of sustainability as a part of the concept sustainable development (SD).

Sustainable development has been incorporated into many levels of society in recent years (Ness et al. [7]). The concept of sustainable development has become an important aspect of many industries worldwide. Sustainability implies the provision of more efficient services that maintain public health and welfare, are cost-effective, and reduce negative environmental impacts, today and into the future (Sahely et al. [8]). One important aspect of sustainability in engineering is the need to use a systematic approach to properly assess the impacts its activities. Sustainable development refers to systems designed and managed to fully contribute to the objectives of society, now and in the future, while maintaining their ecological, environmental and (engineering) integrity (ASCE/UNESCO [9]). Brundtland report defines the sustainable development as development that meets the needs of the present generation without compromising the ability of future generations to meet their own needs (WCED [10]).

The purpose of sustainability assessment is to provide decision-makers with an evaluation of global to local integrated nature-society systems in short and long-term perspectives in order to assist them to determine which actions should or should not be taken in an attempt to make society sustainable (Kates et al. [11]). There is a widely recognised need for individuals, organisations and societies to find models, metrics and tools for articulating the extent to which, and the ways in which, current activities are unsustainable (Singh et al. [12]). This need arises on multiple layers ranging from supra-national (e.g. the negotiation of protocols for environmental protection), national (e.g. via some version of "greening" GDP) and sub-national levels (e.g. in regional development forums) (Ramachandran [13]).

\section{Sustainability Indicators}

Sustainable development indicators (SDI) have the potential to turn the generic concept of sustainability into action. Indicators are simple measures, most often quantitative that represent a state of economic, social and/or environmental development in a defined region often the national level (Ness et al. [7]). Though there are disagreements among those from different disciplines, they have each offered measures or indicators of how to measure the concept. While sustainability indicators, indices and reporting systems gained growing popularity in both the public and private sectors, their effectiveness in influencing actual policy and practices often remains limited.

A principal challenge for the engineer is the development of practical tools for measuring and enhancing the sustainability of urban infrastructure over its life cycle (Sahely et al. [8]). One way of understanding and quantifying these interacting effects is through the use of sustainability indices and indicators. When indicators are aggregated in some manner, the resulting measure is an index. According to Harger \& Meyer [14] indicators should contain the following characteristics: simplicity, (a wide) scope, are quantifiable, allow trends to be determined, tools that are sensitive to change, and allow timely identification of trends. Indicators and indices, which are continuously measured and calculated, allow for the tracking of longer-term sustainability trends from a retrospective point of view (Ness et al. [7]).

According to Walsh [15] the primary purpose of construction related sustainability performance indicators is to commence, in earnest, the practical task of implementing a sustainable approach to the future development and modification of the 'built environment', while also playing our part in ensuring a flourishing future for the 'natural environment' by carrying out sufficient repair to past, present and potential future damage directly or indirectly caused by construction. The indicators have been grouped in the 3Es or dimensions of sustainability assessment. The conventional way of looking at sustainable development presents it as a three dimensional concept composed by the environmental, social, and economic components (Figure 1).
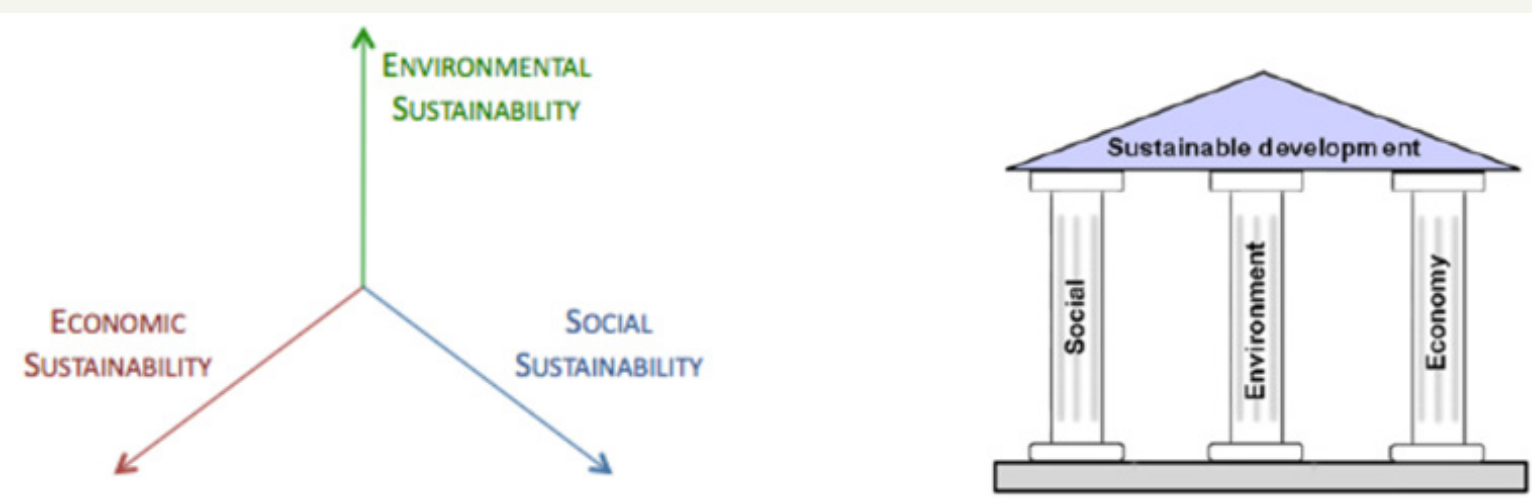

Figure 1: Left: Traditional 3D view of SD.

Right: SD representation (Heijungs et al. [16]).

\section{Environmental Dimension}

Environmental issues are becoming increasingly prominent, often as a consequence of legislation concerning sustainability and producer responsibility (Mundy et al. [17]). Environmental impact across a range of issues such as impact: on air quality; on water 
usage and water quality; on toxicity to human life and to ecosystem functioning; impact on global warming; as well as resource use. In the 1970s the main concern in Europe was acid rain, today it is climate change. The importance of these issues can change over time as society's concerns and priorities change. The BRE guide provides a detailed description of the commonly assessed environmental indicators (BRE [18]). Table 1 presents the relevant adapted environmental indicators from literature for assessing construction materials sustainability. Since material users are increasingly seeking to address environmental issues in their decision making processes, it is becoming increasingly necessary to know what the environmental impacts of products, processes and services are. The challenge is to find reliable environmental performance information in a format that allows it to be factored into decision making (Mundy et al. [17]). Steel, cement, glass, aluminium, plastics, burnt bricks, etc. are energy-intensive materials, commonly used for building construction. Generally, these materials are transported over great distances (Danso [22,23]). Extensive use of these materials can drain the energy resources and adversely affect the environment (Reddy [24]).

Table 1: Indicators for environmental dimension.

\begin{tabular}{|c|c|}
\hline Indicators & sReference(S) \\
\hline Climate change & $\begin{array}{c}\text { Mundy et al. [17], BRE [18], Anderson \& } \\
\text { Thornback [19] }\end{array}$ \\
\hline Ozone layer depletion & $\begin{array}{c}\text { Mundy et al. [17], BRE [18], Anderson \& } \\
\text { Thornback [19], Feifer [20] }\end{array}$ \\
\hline Human toxicity & Mundy et al. [17], BRE [18], \\
\hline Ecotoxicity & $\begin{array}{c}\text { Mundy et al. [17], BRE [18], Anderson \& } \\
\text { Thornback [19] }\end{array}$ \\
\hline $\begin{array}{l}\text { Acidification (Acid } \\
\text { deposit) }\end{array}$ & $\begin{array}{c}\text { Mundy et al. [17], BRE [18], Anderson \& } \\
\text { Thornback [19] }\end{array}$ \\
\hline Fossil fuel depletion & Mundy et al. [17], BRE [18], \\
\hline Solid waste & Mundy et al. [17], BRE [18], \\
\hline Minerals extraction & $\begin{array}{c}\text { Mundy et al. [17], BRE [18], Anderson \& } \\
\text { Thornback [19] }\end{array}$ \\
\hline Water extraction & $\begin{array}{c}\text { Mundy et al. [17], BRE [18], Anderson } \\
\text { \& Thornback [19], Feifer [20], Ugwua \& } \\
\text { Haupt [21] }\end{array}$ \\
\hline Freight transport & Mundy et al. [17] \\
\hline Photochemical oxidation & BRE [18] \\
\hline
\end{tabular}

\section{Acidification (AD)}

Acidic gases such as sulphur dioxide $\left(\mathrm{SO}_{2}\right)$ and nitrogen oxides (NOx) given off in fuel combustion react with water in the soil or in the atmosphere (where it forms "acid rain"). Acid deposition can damage ecosystems and erode materials. Acidification Potential (AP) is expressed using the reference unit, $\mathrm{kg} \mathrm{SO}_{2}$ equivalent (BRE [18]). The main gases that cause acid deposition are nitrogen oxides (NOx) and sulphur oxides (SOx); ammonia and hydrogen fluoride also cause acidification but to a much lesser extent. SOx and NOx are commonly emitted as a result of combustion of fossil fuels, particularly from coal and oil fired power generation and diesel vehicles or in manufacturing processes using coal, all of which have relevance to the construction industry (Anderson \& Thornback [19]).

\section{Climate change (CC)}

Climate change refers to the change in global temperature caused via the greenhouse effect by the release of "greenhouse gases" such as carbon dioxide by human activity. There is now scientific consensus that the increase in these emissions is having a noticeable effect on climate. Raised global temperature is expected to cause climatic disturbance, desertification, rising sea levels and spread of disease (BRE [18]). Embodied carbon is the Carbon Dioxide $\left(\mathrm{CO}_{2}\right)$ or greenhouse gas (GHG) emissions associated with the manufacture and use of a product or service. For construction products this means the $\mathrm{CO}_{2}$ or GHG emission associated with extraction, manufacturing, transporting, installing, maintaining and disposing of construction materials and products (Anderson \& Thornback [19]).

\section{Fossil fuel depletion (FD)}

This impact category indicator is related to the use of fossil fuels. Fossil fuels provide a valuable source of energy and feedstock for materials such as plastics. Although there are alternatives, these are only able to replace a small proportion of our current use. Fossil fuels are a finite resource and their continued consumption will make them unavailable for use by future generations. BRE use an absolute measure based on the energy content of the fossil fuel. This does not take into account the relative scarcity of different fossil fuels, but in fact these only vary by $17 \%$ between coal (the most common) and gas (the most scarce) (BRE [18]).

\section{Human toxicity (HT)}

The emission of some substances can have impacts on human health. Characterisation factors, expressed as Human Toxicity Potentials (HTP), are calculated using USES-LCA, as with Ecotoxicity, which describes fate, exposure and effects of toxic substances for an infinite time horizon (BRE [18]). Toxicity indicators aim to quantify the degree to which a particular substance causes damage to living organisms. There are a number of different indicators which indicate toxicity to different groups of organisms in different ecosystems. Assessments of toxicity are based on guidelines for tolerable concentrations in air and water, tolerable daily intake and acceptable daily intake for human toxicity (Anderson \& Thornback [19]). Issues relating to toxicity generate much debate in the construction industry and beyond. Designers should carefully review the material supplier's guidance and note any relevant regulations, codes and standards appropriate to different materials. They should also consider the context and application within which the materials are to be used to ensure that industry-specific regulations/standards are adhered to. Many of the chemicals used in society have not undergone a risk assessment and assessment techniques are still developing, something that manufacturers of construction products should also be aware of (Anderson \& Thornback [19]). 


\section{Mineral depletion (MR)}

This impact category indicator is related to the extraction of virgin abiotic material e.g. extraction of aggregates/metal ores/ minerals/earth etc. The extraction of such substances can mean that the natural carrying capacity of the earth is exceeded and make them unavailable for use by future generations. This indicator relates purely to resource use, not other environmental impacts which might be associated with mining or quarrying, or the relative scarcity of resources (BRE [18]). Raw material/mineral extraction is of significance to the construction industry due to the quantities of material involved in the production of construction products. Raw material use can be presented as an inventory list of materials required, giving more detailed information about the resources consumed than an aggregated indicator (BRE [18]).

\section{Solid waste (SW)}

This category represents the environmental issues associated with the loss of resource implied by the final disposal of waste. Any waste that is disposed of in landfill or incinerated without energy recovery will be included. The aspect is also used in other characterisation methodologies, for example the Dutch EcoIndicator 30 and the Swiss Ecopoints 31, the characterisation factor is based on the mass of solid waste (BRE [18]).

\section{Ozone depletion (OD)}

Ozone-depleting gases cause damage to stratospheric ozone or the "ozone layer" by releasing free radical molecules which breakdown ozone $\left(\mathrm{O}_{3}\right)$. Damage to the ozone layer reduces its ability to prevent ultraviolet (UV) light entering the earth's atmosphere, increasing the amount of carcinogenic UVB light hitting the earth's surface (Anderson \& Thornback [19]). Damage to the ozone layer by chlorinated and brominated chemicals increases the amount of harmful ultraviolet (UV) light hitting the earth's surface. Although the use of chemicals such as CFCs and HCFCs have been phased out in Europe following the 1987 Montreal Protocol, much existing refrigeration equipment and insulation foam still contains CFCs and HCFCs (BRE [18]). Common sources of these gases are refrigerants and blowing agents. In the construction materials industry, steps have been taken to replace ozone depleting insulating foam blowing agents with non-ozone depleting gases such as HFCs (Anderson \& Thornback [19]).

\section{Water extraction (WE)}

Around the world, water is becoming an increasingly scarce resource, due to increased demand, and changes in patterns of rainfall. To recognise the value of water as a resource, and the damage that over extraction from rivers and aquifers can cause this category includes all water extraction, except seawater and rainwater (BRE [18]). Within the construction industry, most existing measures used in EPD consider water use, taking into consideration water which is moved from one state or location to another, but ignoring water which is returned to its original source, such as river water which is extracted for cooling but then returned to the same river. However there are differences, for example, in terms of how they treat water taken from a river and returned to the sewer, water used to generate hydroelectricity, or ground water returned to surface water (Anderson \& Thornback [19]).

\section{Social Dimensions}

Social sustainability means striving towards equal participation of different groups in the decision-making, planning, and production of housing (Bramley et al. [25]). It is important to avoid social exclusion of different gender, ethnic and low income groups. This is especially important in developing countries where low-income groups are often excluded in official planning processes and resort to resolving their immediate housing needs through informal settlement approaches (French [26]). Housing is critical to meeting basic human needs in shelter, but it is also important for the social development of communities and societies. Although traditionally housing policy has focused on fundamental social needs fulfilment, such as affordable, decent and healthy homes, it also has to ensure that housing achieves intermediate social needs such as transport and facilities, as well as the ultimate needs of the development of human and social capital and capacity (education, skills, health, and values), cohesion and wellbeing in communities and society at large (good relationships, participation, inclusion and equity, security, sense of community) (Golubchikov \& Badyina [27]). Table 2 presents the relevant adapted social indicators from literature for assessing construction materials sustainability.

Table 2: Indicators for social dimension.

\begin{tabular}{|c|c|}
\hline Indicators & Reference(S) \\
\hline $\begin{array}{l}\text { Cultural heritage } \\
\text { preservation }\end{array}$ & $\begin{array}{c}\text { Ugwua \& Haupt [21], Golubchikov \& } \\
\text { Badyina [27], UN Habitat [28], DEAC Tool } \\
\text { et al. [29] }\end{array}$ \\
\hline Aesthetic quality & $\begin{array}{c}\text { Golubchikov \& Badyina [27], DEAC Tool et } \\
\text { al. [29], Luong et al. [30] }\end{array}$ \\
\hline $\begin{array}{l}\text { Choice and security of } \\
\text { tenure }\end{array}$ & $\begin{array}{l}\text { Golubchikov \& Badyina [27], Halme et al. } \\
\qquad[31]\end{array}$ \\
\hline Housing for all & Golubchikov \& Badyina [27] \\
\hline $\begin{array}{l}\text { Empowerment and } \\
\text { participation }\end{array}$ & $\begin{array}{l}\text { UN Habitat [28], UN Habitat [32], Halme et } \\
\text { al. [31] }\end{array}$ \\
\hline Adaptability & ISO 21929-1 [33], Bossel [34] \\
\hline Accessibility & Sahely et al. [8], ISO 21929-1 [33] \\
\hline Thermal comfort & $\begin{array}{l}\text { Sahely et al. [8], Feifer [20], DEAC Tool et al. } \\
\text { [29], Halme et al. [31], ISO 21929-1 [32] }\end{array}$ \\
\hline
\end{tabular}

\section{Empowerment and participation}

Social sustainability has many dimensions. One of them is the empowerment of people from all income, age and ethnic groups, regardless of gender, to be a part of housing construction processes and the decision making behind them (UN Habitat [28]). People should be involved in information gathering, planning, implementation, maintenance and monitoring processes related to housing. 


\section{Cultural heritage}

The most well-known and accepted meaning of cultural sustainability is protecting cultural built heritage. Housing can have a historic, aesthetic, spiritual or symbolic cultural heritage value even if it may not be economically valuable (UN Habitat [28]). Protecting cultural heritage can make people closer to their traditions and is a responsibility in terms of preserving history (French [26]). Cultural heritage is producing and maintaining housing that is culturally responsive and appropriate to the occupants who use it and the society in which it is located. This means aspects such as the form, design, spatial layout, materials, etc., must reflect the worldviews, values, ideals, lifestyles of its occupants and the cultural groups that it serves (UN Habitat [28]).

\section{Economic Dimension}

Largely, decisions concerning the design, construction, maintenance, and demolishing of structures have been based on cost analysis. Today, economic indicators such as capital costs and operation and maintenance costs continue to play an important role in decision making as part of a larger set of indicators (Sahely et al. [8]). The urban development sustainability assessment model (UD-SAM) proposed the multiplier effect of jobs and whole-life value as economic impacts. The inclusion of an indicator that can attempt to measure these in the scheme is now considered (Forbes et al. [35]). In principle, incorporation of the economic dimension of sustainability in the scheme would take account of whole-life costs. However, study by Forbes et al. [35] developed an approach that uses the capital construction cost of dwellings because sufficient reliable data for whole-life costs was unavailable. The relevant adapted social indicators from literature for assessing construction materials sustainability can be found in Table 3 .

Table 3: Indicators for economic dimension.

\begin{tabular}{|c|c|}
\hline Indicators & Refernce(S) \\
\hline Initial cost & Ugwua \& Haupt [21], ISO 21929-1 [33] \\
\hline Maintenance cost & ISO 21929-1 [33], Luong et al. [30] \\
\hline Operational cost & Ugwua \& Haupt [21], Luong et al. [30] \\
\hline Job creation & $\begin{array}{r}\text { UN Habitat [28], Halme et al. [31], UN ISD [36], } \\
\text { Batagarawa [37], DESD [38] }\end{array}$ \\
\hline Long-term savings & UN Habitat [28] \\
\hline Tourism & Ugwua \& Haupt [21], DESD [38], Hoballah [39] \\
\hline
\end{tabular}

\section{Job creation}

Jobs can be created through the housing sector, which is especially important in the context of developing countries. Employment can be created through new construction and retrofitting, production of energy efficient or recycled materials and though renewable energy and technologies related to it (UN Habitat [28]). The informal sector can, and should be engaged in developing countries, which increases the building sector's potential for poverty reduction by building on existing skills, networks and capabilities even though they operate outside the formal construction sector (UNEP [40]).

\section{Long-term savings}

Low-cost sustainable housing offers significant economic advantages in terms of energy-saving during use/occupation making sustainable housing cheaper in long-term compared to conventional housing (UN Habitat [41]). However, the initial investment needed is usually higher than conventional housing and thus given the limited access to housing finance in developing countries, green building strategies are not currently widely adopted (Giddings [42]).

\section{Analytical Hierarchical Process in Sustainable Construction Materials Assessment}

Analytic Hierarchy Process (AHP) is one of the most widely used multiple-criteria decision-making tools for structuring, measurement, and synthesis. The AHP has been applied to a wide range of problem situations: selecting among competing alternatives in a multi-objective environment, the allocation of scarce resources, and forecasting (Forman \& Gass [43]). AHP is one of the multi-criteria decision analysis (MCDA) methods that help decision makers to make decisions when several conflicting criteria need to be evaluated (Ishizaka et al. [44]). AHP was developed by Thomas L. Saaty in the 70's, the analytic hierarchy process is a MCA approach in which factors are arranged in a hierarchic structure (Saaty [45]). This methodology decomposes a complex decisionmaking problem into smaller elements by constructing a hierarchy, starting from the overall goal of the decision, descending to criteria, sub-criteria, and finally the alternatives. Weights are generated endogenously by implicitly revealing preferences in pairwise comparisons of alternatives (Janeiro [46]).

The most important use of the AHP is the decision making of selected problems in a multi-criteria environment. Its methodology includes comparisons of objectives and alternatives in pairwise manner. It is based on the well-defined mathematical structure of consistent matrices and their associated right-eigenvector's ability to generate true or approximate weights (Saaty [45]). The AHP converts individual preferences into ratio-scale weights that are combined into linear additive weights for the associated alternatives. These resultant weights are used to rank the alternatives and thus assist the decision maker (DM) in making a choice or forecasting an outcome Forman \& Gass [43].

In the construction industry, the AHP is much appropriate for measuring the sustainability of its activities. Sustainability implies the provision of more efficient services that maintain public health and welfare, cost-effective, and reduce negative environmental impacts, presently and in the future. Sustainability takes into account social, economic and environmental issues. The built environment has a significant impact on all three, although the exact impact is a matter of current debate (Forbes et al. [35]). For example, from an environmental perspective, buildings in the UK 
account for around a half of total carbon dioxide emissions and a third of landfill waste (BERR [47]). Since construction activities have social, economic and environmental implications, AHP can be used to measure its impact on the society and also measure the preference of the stakeholders of construction materials in the industry.

\section{AHP procedure}

Like several other MCDM methods such as ELECTRE, MacBeth, SMART, PROMETHEE and UTA (Belton \& Stewart [48], Figueira \& Springer-Verlag [49]), AHP is based on four steps: problem modelling, weights valuation, weights aggregation and sensitivity analysis (Ishizaka et al. [44])

\section{Problem modelling}

In the problem modelling, a decision-making structure of the problem is made. This can be divided into three parts: goal (sustainability analysis), criteria or evaluative dimension (environmental, social, economic and their sub-criteria/factors) and alternatives. AHP has the advantage of permitting a hierarchical structure of the criteria, which provides users with a better focus on specific criteria and sub-criteria when allocating the weights. The hierarchical structure proposed for construction materials sustainability assessment is presented in Figure 2, based on the adapted indicators for the three dimensions.

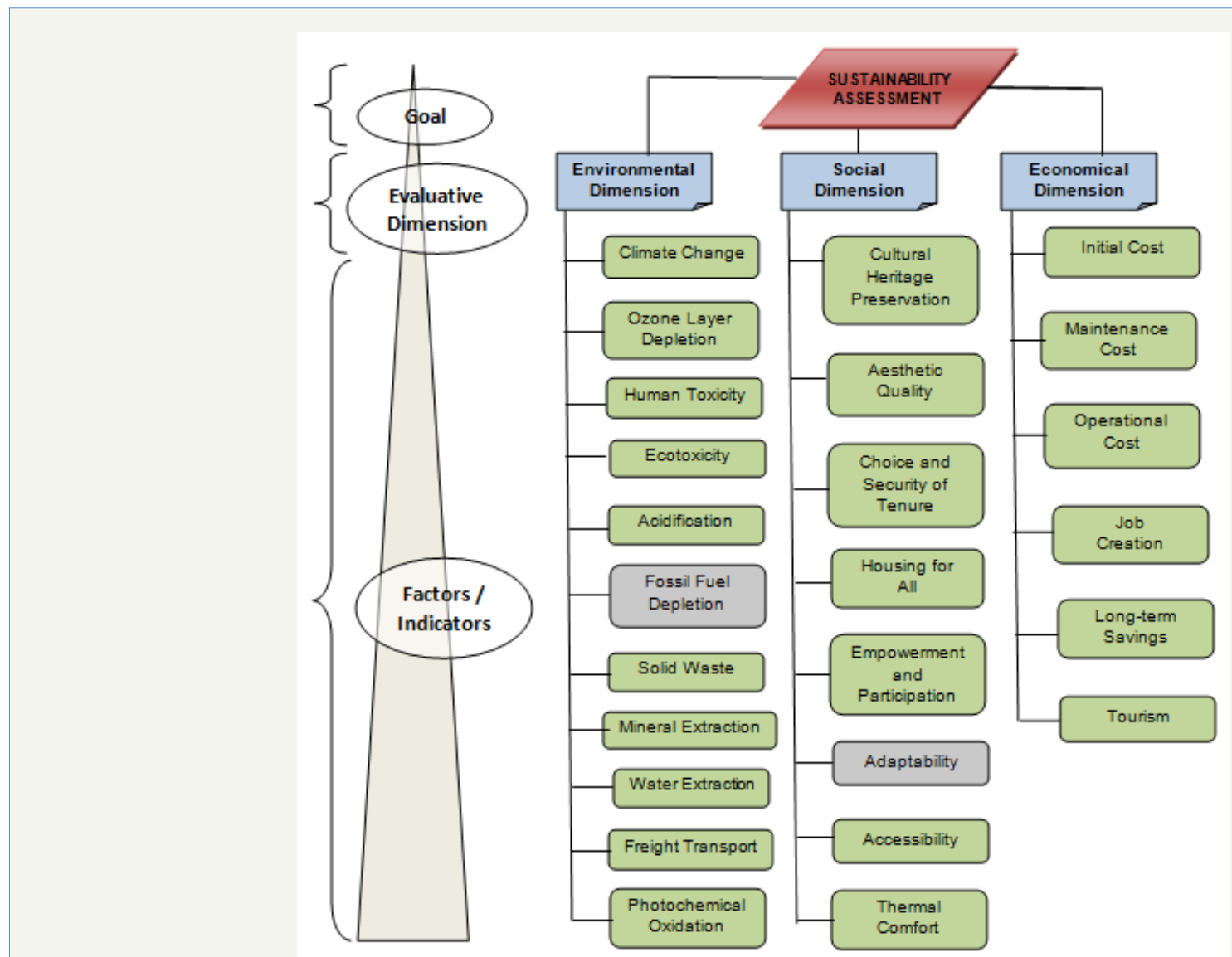

Figure 2: Hierarchical structure for construction materials sustainability assessment.

The goal of the structure is the development of sustainability assessment for construction materials. The evaluative dimensions are the three main dimensions for the sustainability assessment. The factors are the indicators under each dimension for assessing the construction materials. This hierarchical structure provides a clear structure for the assessment of sustainability construction materials.

\section{Weights valuation (Pairwise comparisons)}

Once the model is built, the next step is to evaluate the elements by making pairwise comparisons. A pairwise comparison is the process of comparing the relative importance, preference, or likelihood of two elements (objectives) with respect to another element (the goal). This allows consistency and cross checking between the different pairwise comparisons. There are three different paired comparison types, importance, preference and likelihood (Expert Choice [50]). Importance is most appropriate when comparing objectives or criteria. Preference is appropriate when comparing alternatives with respect to their covering objective. Likelihood is appropriate when comparing the likelihood of uncertain events or scenarios, such as in risk analysis.

AHP uses a ratio scale, which, contrary to methods using interval scales (Kainulainen et al. [51]), requires no units in the comparison. One of AHP's strengths is the possibility to evaluate quantitative as well as qualitative criteria and alternatives on the same preference 
scale of nine levels. These can be numerical (Table 4), verbal or graphical. Since judgments about the relative importance of the objectives may depend on the alternatives being considered, it is recommend that judgments be made from the "bottom up", that is first for the alternatives, then for the sub-objectives, and then for the objectives. Explanation of the comparison is presented in Table 5. Once the comparisons matrices are filled, priorities can be calculated. The traditional AHP uses the eigenvalue method.

Table 4: Numerical representations of verbal judgments.

\begin{tabular}{|c|c|}
\hline Interpretation & Scale \\
\hline Extreme & 9 \\
\hline Very strong to extreme & 8 \\
\hline Very strong & 7 \\
\hline Strong to very strong & 6 \\
\hline Strong & 5 \\
\hline Moderate strong & 4 \\
\hline Moderate & 3 \\
\hline Equal to moderate & 2 \\
\hline Equal & 1 \\
\hline
\end{tabular}

Table 5: Comparison scale (Yang \& Shi [52]).

\begin{tabular}{|c|c|c|}
\hline Intensity & Definition & Explanation \\
\hline 1 & Equal importance & $\begin{array}{c}\text { Two factors contribute equally to } \\
\text { the objective }\end{array}$ \\
\hline 3 & $\begin{array}{c}\text { Moderate importance } \\
\text { of one over another }\end{array}$ & $\begin{array}{c}\text { Experience and judgment favour } \\
\text { one factor over another }\end{array}$ \\
\hline 5 & $\begin{array}{c}\text { Essential or strong } \\
\text { importance }\end{array}$ & $\begin{array}{c}\text { Experience and judgment strongly } \\
\text { Favour one factor over another }\end{array}$ \\
\hline 7 & $\begin{array}{c}\text { Very strong } \\
\text { importance }\end{array}$ & $\begin{array}{c}\text { An factor is strongly favoured and } \\
\text { its dominance demonstrated in } \\
\text { practice }\end{array}$ \\
\hline 9 & Extreme importance & $\begin{array}{c}\text { The evidence of favouring one } \\
\text { factor over another is of the highest } \\
\text { possible order of affirmation }\end{array}$ \\
\hline
\end{tabular}

2, 4, 6, 8 Intermediate values when compromise is needed

Due to the fact that our world is inconsistent by nature, a minimal consistency is required to derive meaningful priorities, and therefore a consistency test must be done. As priorities make sense only if derived from consistent or near consistent matrices, a consistency check must be applied. The inconsistency measure is useful for identifying possible errors in judgments as well as actual inconsistencies in the judgments themselves. In general, the inconsistency ratio should be less than 0.1 or so to be considered reasonably consistent (Expert Choice [50]).

\section{Weights aggregation}

The weights aggregation seeks to synthesize the local priorities across all criteria in order to determine the global priority. The historical AHP approach (called later distributive mode) adopts an additive aggregation (5) with normalization of the sum of the local priorities to unity (Ishizaka et al. [44]).
A synthesis can be done for either the entire model or a portion of your model. Ideal Synthesis is the ideal mode which assigns the full priority of each covering objective to the alternative that ranks highest under it. The other alternatives receive a percentage of the priority in proportion to the highest alternative. The Ideal Synthesis should be used when you are interested in only one alternative and the remaining alternatives are no longer relevant. Distributive Synthesis is used when you are interested in prioritizing alternatives from which you may pick more than one. The distributive synthesis distributes the priority of the objectives among the alternatives, thereby dividing each objective's priority into proportions relative to the percentage of the alternatives. Because each synthesis mode combines priorities differently, you will notice that each mode may yield different, although normally very similar results (Expert Choice [50]).

Millet \& Saaty [53] gave some guidance on which normalization to use. If we are in a closed system (that is no alternative will be added or removed), then the distributive mode should be used. If we are in an open system (that is alternatives can be added or removed) and we allow our preferences for alternatives to be dependent on other alternatives (in other words, we accept the rank reversal phenomenon), then the distributive mode is indicated. If we are in an open system and you do not want that other alternatives to affect the outcome, then the ideal mode is recommended. Based on these observations, Expert Choice has been modified to support the two modes.

\section{Sensitivity analysis}

The sensitivity analysis in Expert Choice varies the weights of the criteria as input data. It is also imaginable to have in future a sensitivity analysis by varying interactively the local priorities of the alternatives (there is no mathematical challenge in it). However, sensitivity analysis is a fundamental process in the decision with AHP; it has received little attention from the academic literature (Ishizaka et al. [44]).

Sensitivity analyses from the goal shows the sensitivity of the alternatives with respect to all the objectives below the goal. It can also be performed from the nodes under the goal if the model has more than three levels to show the sensitivity of the alternatives with respect to an objective or sub-objective. When performing a sensitivity analysis you may vary the priorities of the objectives and observe how the priorities of the alternatives would change. There are five types of sensitivity analysis: dynamic, performance, gradient, head to head, and two-dimensional (2D Plot) (Expert Choice [50]).

\section{Conclusion}

This paper reviewed the general and relevantavailable indicators for measuring sustainable construction materials. It outlined main idea behind sustainability assessment. It also reviewed the critical sustainability indicators which are grouped under the 3Es, thus environmental dimension, social equity dimension and economic dimension. Furthermore, it highlighted the analytical hierarchical process in sustainable construction materials assessment. The 
paper therefore, concludes that it is important to identify the relevant sustainable indicators for construction materials and be able to measure the indicators following the analytical hierarchical process [54-56].

\section{References}

1. Keung J (2007) Sustainable construction materials for buildings, Building and Construction Authority, Singapore ISBN 978-981-05-7990-

2. Wahlström M, Ylijoki JL, Järnström, Kaartinen H, Erlandsson T, et al. (2014) Environmentally sustainable construction products and materials-assessment of release and emissions. Nordic Innovation Oslo ISBN 978-82-8277-060-6.

3. Peach J (2010) Five sustainable building materials that could transform construction.

4. Khatib JM (2009) Sustainability of construction materials, $\left(2^{\text {nd }}\right.$ edn $)$, Woodhead Publishing, CRC Press, UK.

5. Fielding R, Boak R, Jowett A (2012) Review of sustainable building materials \& design. Build It International, UK.

6. Mailler M (2008) Sustainability assessment of an IAIA educationa \& networkin forum. $28^{\text {th }}$ Annual Conference of the International Association for Impact Assessment. Perth, Western Australia.

7. Ness B, Piirsalu UE, Anderberg S, Olsson L (2007) Categorising tools for sustainability assessment. Ecological Economics 60(3): 498-508.

8. Sahely HR, Kennedy CA, Adams BJ (2005) Developing sustainability criteria for urban infrastructure systems. Canadian Journal of Civil Engineering 32(1): 72-85.

9. ASCE/UNESCO (1998) Sustainability criteria for water resource systems. American society of civil engineers (ASCE).

10. Wced (1987) Our common future. Oxford University Press: Oxford University, England.

11. Kates RW, Clark WC, Corell R, Hall MJ, Jaeger CC, et al. (2001) Sustainability science. Science 292: 641-642.

12. Singh RK, Murty HR, Gupta SK, Dikshit AK (2009) An overview of sustainability assessment methodologies. Ecological indicatots 9: 189212.

13. Ramachandran N (2000) Monitoring sustainability: indices and techniques of analysis, Concept publishing company, New Delhi, India.

14. Harger JRE, Meyer FM (1996) Definition of indicators for environmentally sustainable development. Chemosphere 33: 1749-1775.

15. Walsh CJ (2002) Construction related sustainability performance indicators. Sustainable Design International 1-7.

16. Heijungs R, Huppes G, Guinée JB (2010) Life cycle assessment and sustainability analysis of products, materials and technologies. Toward a scientific framework for sustainability life cycle analysis. Polymer Degradation and Stability 95: 422-428.

17. Mundy J, Bre, Garston, Watford, Herts (2003) Life cycle assessment. FEG.

18. BRE (2007) Methodology for environmental profiles of construction products: product category rules for type III environmental product declaration of construction products. Gartson: BRE.

19. Anderson J, Thornback J (2012) A guide to understanding the embodied impacts of construction products, Construction Products Association, London.

20. Feifer L (2011) Sustainability indicators in buildings: identifying key performance indicators. International Initiative for a Sustainable Built Environment.

21. Ugwua 00, Haupt TC (2007) Key performance indicators and assessment methods for infrastructure sustainability-a South African construction industry perspective. Building and Environment 42(2): 665-680

22. Danso H (2015a) Use of agricultural waste fibres as enhancement of soil blocks for low-cost housing in Ghana. PhD, University of Portsmouth, England.

23. Danso H, Martinson DB, Ali M, Williams JB (2015b) Physical, mechanical and durability properties of soil building blocks reinforced with natural fibres. Construction and Building Materials 101(1): 797-809.

24. Reddy BVV (2004) Sustainable building technologies. Current Science 87.

25. Bramley G, Dempsey N, Power S, Brown C (2006) What is 'social sustainability', and how do our existing urban forms perform in nurturing it? Sustainable Communities and Green Futures' track, Planning research conference. Bartlett School of Planning, UCL, London.

26. French M (2012) Change by design: building community through participatory design, Urban Culture Press, New Zealand.

27. Golubchikov 0, Badyina A (2012) Sustainable housing for sustainable cities: a policy framework for developing countries, nairobi, united nations human settlements programme (UN-Habitat).

28. UN Habitat (2012) Going green: a handbook of sustainable housing practices nairobi, kenya united nations human settlements programme.

29. Deac T, Langford DA, Macleod I, Maver T, Dimitrijevic B (2002) Durability, adaptability and energy conservation (DAEC) assessment tool. International Journal of Environmental Technology and Management 2: 142-159.

30. Luong S, Liu K, Robey J (2012) Sustainability assessment framework for renewable energy technology. Technology for sustainable built environment conference. University of Reading, United Kingdom.

31. Halme M, Jasch C, Scharp M (2004) Sustainable home services? Toward household services that enhance ecological, social and economic sustainability. Ecological Economics 51(1-2): 125-138

32. UN Habitat (2009) Anchoring Homes, UN-Habitat's people's process in Aceh and Nias after the tsunami, 2007, Post Tsunami Aceh-Nias Settlement and housing Recovery Review, UN-Habitat.

33. ISO 21929-1 (2011) Sustainability in building constructionsustainability indicators. Part 1: framework for the development of indicators and a core set of indicators for buildings. International Organization for Standardization

34. Bossel H (1999) Indicators for sustainable development: Theory, Method, Applications. IISD.

35. Forbes D, Haram EM, Smith S, Horner M (2011) Incorporating an economic measure in sustainability assessment. Proceedings of the Institution of Civil Engineers: Urban Design and Planning 164: 147-154

36. UN ISD (2007) Indicators of Sustainable Development: Guidelines and Methodologies, ( $3^{\text {rd }}$ edn), New York, United Nations.

37. Batagarawa RL (2011) Sustainability appraisal of waste management in Nigeria: development and evaluation of an index based tool. $\mathrm{PhD}$, University of Portsmouth, England.

38. Desd (2007) Indicators of sustainable development: guidelines and methodologies ( $3^{\text {rd }}$ edn), New York, United Nations.

39. Hoballah A (2012) Sustainable building: driver to transformative change. SBCI Symposium. Philadelphia.

40. UNEP (2011) Buildings: investing in energy and resource efficiency. United Nations Environment Programme UNEP.

41. Habitat UN (2011) Affordable land and housing in Africa united nations human settlement programme.

42. Giddings B, Hopwood B, O’Brien G (2002) Environment, economy and society: fitting them together into sustainable development. Sustainable development 10(4): 187-196. 
43. Forman EH, Gass SI (1999) The analytic hierarachy process-An exposition operations research 49: 469-486.

44. Ishizaka A, Labib A (2009) Analytic hierarchy process and expert choice: benefits and limitations. Insight 22: 201-220.

45. Saaty TL (1994) How to make a decision: the analytic hierarchy process Interfaces 24: 19-43.

46. Janeiro L (2011) Towards a methodology for the sustainability assessment of technologies: integration of environmental, social and economic indicators. MSc in Sustainable Development, Universiteit Utrecht, Netherlands.

47. Berr DFB (2008) Strategy for sustainable construction. Department for Business, Enterprise and Regulatory Reform.

48. Belton V, Stewart TJ (2002) Multiple criteria decision analysis: an integrated approach, boston, Kluwer academic publishers, USA.

49. Figueira J, Greco S, Ehrgott M (2005) Multiple criteria decision analysis: state of \& springer-verlag. Multiple Criteria Decision Analysis: State of the Art Surveys, New York, Springer-Verlag.

50. Expert Choice (2002) Advanced decision support software for the millennium: advanced decision support software for the millennium. Pittsburgh, PA patent application.
51. Kainulainen T, Leskinen P, Korhonen P, Haara A, Hujala T (2009) A statistical approach to assessing interval scale preferences in discrete choice problems. Journal of the Operational Research Society 60: 252258.

52. Yang J, Shi P (2002) Applying analytic hierarchy process in firm's overall performance evaluation: a case study in China. International Journal of Business 7: 29-46

53. Millet I, Saaty TL (2000) On the relativity of relative measuresaccommodating both rank preservation and rank reversals in the AHP. European Journal of Operational Research 121: 205-212.

54. Bramley G, Dempsey N, Power S, Brown C (2006) What is 'social sustainability', and how do our existing urban forms perform in nurturing it? Sustainable Communities and Green Futures' track, Planning research conference. Bartlett School of Planning, UCL, London.

55. Ishizaka A, Pearman C, Nemery P (2012) AHPSort: an AHP based method for sorting problems. International Journal of Production Research 50: 4767-4784.

56. Saaty TL (1990) How to make a decision: The analytic hierarchy process. European Journal of Operational Research 48: 9-26.

\section{Your subsequent submission with Crimson Publishers will attain the below benefits}

- High-level peer review and editorial services

- Freely accessible online immediately upon publication

- Authors retain the copyright to their work

- Licensing it under a Creative Commons license

- Visibility through different online platforms

- Global attainment for your research

- Article availability in different formats (Pdf, E-pub, Full Text)

- Endless customer service

- Reasonable Membership services

- Reprints availability upon request

One step article tracking system 